ROCZNIKI HUMANISTYCZNE

Volume 67, issue 4 - 2019

SELECTED PAPERS IN ENGLISH

DOI: http://dx.doi.org/10.18290/rh.2019.67.4-3en

JOWITA JAGLA

\title{
FROM A NOBLE SUBSTANCE TO AN IMITATIVE BODY. THE IMAGE AND MEANING OF WAX FIGURES IN A VOTIVE OFFERING
}

\section{THE MEANING OF WAX AND CANDLE}

Among a rich selection of votive gifts, wax votive offerings deserve special attention. They were common as early as in the Middle Ages and used until the $20^{\text {th }}$ century. The established custom of using wax material for votive offerings was attributed to the multi-layered symbolism of wax as a rare and precious substance known since antiquity. It was already Pliny the Elder who noted that wax was an unusual product made by bees - the only animals created for the benefit of people-with thousands of applications in everyday life! ${ }^{1}$

In the Middle Ages, wax became a religious symbol. Pope Gelasius (died 496), in his Sacramentarium Gelasianum, praised bees as modest and pure beings, building their homes of wax and bearing offspring, which Gelasius

Jowita Jagla, PhD - Head of the Department of History of Medicine, Nicolaus Copernicus Museum in Frombork; mailing address: Muzeum Mikołaja Kopernika, ul. Katedralna 8, 14-530 Frombork; e-mail: jovita7@wp.pl

The Polish version of the article was published in Roczniki Humanistyczne vol. 62, issue 4 (2014).

${ }^{1}$ PLiniusz, Historia naturalna, trans. into Polish by Irena and Tadeusz Zawadzki, (WrocławKraków: Zakład Narodowy im. Ossolińskich, 1961), 144-145. Wax is a product of the abdominal glands of worker honeybees. Pliny believed that it was produced from flowers, "and afterwards honey, wax from flowers, bee-glue from the droppings of the gum-producing treesthe sap, glue and resin of the willow, elm and reed," ibidem, 145). This view persisted as long as until the $18^{\text {th }}$ century. In 1740 Réaumur was the first to discover that wax is in fact a digestive product, see Ursula PFISTERMEISTER, Wachs. Volkskunst und Brauch (Nürnberg: Hans Carl, 1982), 10. 
likened to Christ who, like a bee from a wax cell, came into the world through his Father's mouth. ${ }^{2}$ Importantly, light itself symbolized God (1 John 1:5); God is clothed with light (Psalm 103:2) and dwells in it (1 Timothy 6:16). Christ also called himself the light of the world (John 8:12), ${ }^{3}$ and his followers were and are the light ("You are the light of the world," Matthew 5:14). Regarding God as the light contributed to the great role of light in the liturgy and its many gestures and rites, ${ }^{4}$ such as the lighting of the Paschal candle (the symbol of the Risen Christ), the lighting of the Paschal candle at funerals, the lighting of a candle from the Paschal during the baptism ceremony (a symbol of receiving the grace of faith and adoption from Christ), blessing candles on the Feast of the Presentation of the Lord. ${ }^{5}$ Particularly, the liturgy of the light is permeated with such symbolism with such gestures as: the lighting of the Paschal candle from a sacred fire, carrying the Paschal into a darkened church with the minister calling of Lumen Christi, the lighting of candles held by the faithful from the Paschal, ${ }^{6}$ the chanting of the Exultet. ${ }^{7}$ It is evident that candles had a multidimensional use in the liturgy. In addition to alluding to divinity, they also (simply) referred to the spiritual world, ${ }^{8}$ expressed faith, are a sign of love and entrustment, ${ }^{9}$ and their flame symbolized everything that soars and becomes firm. ${ }^{10}$

In the centuries that followed, candles and wax began to play an increas ingly important role in the folk religiousness of many countries; they were readily employed in important church holidays and apotropaic gestures, especially during the Feast of the Presentation of the Lord (Candlemas). For

\footnotetext{
${ }^{2}$ Johannes NEUHARDT, "Das Wachs im Kult und Volksfrommen Brauchtum der römischen Kirche," in Köstlich Altes Wachsgebild. II. Sonderschau des Dommuseums zu Salzburg. Mai-Oktober 1977, (Salzburg: Dommuseum 1977), 3-4. An emotional attitude towards bees would be present in folk culture until the early 20th century. Bees would be considered extraordinary creatures blessed with a soul. They were believed to be very attached to their keeper and to die once he passed away. People would not kill bees and would not use foul language in their presence; when visiting a beekeeper, the visitors would first greet the bees to be blessed with happiness, cf. Ludwik DuBIEL, "Wiedza, magia i folklor pszczelarski w tradycyjnej hodowli pszczół na Górnym Śląsku," Zeszyty Gliwickie 10 (1973): 43-66.

${ }^{3}$ Bogusław NAdOLSKI, Liturgika, t. I: Liturgika fundamentalna (Poznań: Pallotinum, 1989), 129.

${ }^{4}$ Michael KunZLER, Liturgia Kościoła, translated by Lucjan Balter (Poznań: Pallotinum, 1999), 234.

${ }^{5}$ NADOLSKI, Liturgika, 130

${ }^{6}$ KunZler, Liturgia Kościoła, 650-651.

${ }^{7}$ Bogusław NADOLSKI, Leksykon liturgii (Poznań: Pallotinum, 2006), 1123.

${ }^{8}$ KUNZLER, Liturgia Kościoła, 230.

${ }^{9}$ Rudolf KRISS, Nina GOCKERELL, Bilder und Zeichen der Frömmigkeit (München: Bayerisches Nationalmuseum, 1995), 102.

${ }^{10}$ Romano GuARDINI, Znaki święte, translated by Józef Birkenmajer (Wrocław: Wydawnictwo Wrocławskiej Księgarni Archidiecezjalnej, 1982), 50-51.
} 
example, in many regions of Poland, a special candle (after its blessing at church) decorated with periwinkle, asparagus or fern, tied with linen cloth and a ribbon (white or blue: the colours of Our Lady) is taken home for the purpose of performing multiple defensive and protective rituals. The candle smoke was used to produce a cross on the lintel of the doorway of the house and outbuildings in order to keep evil away. It was also placed by a home altar, next to a holy image or painting; held by the window during a storm to protect the household against fire; its smoke was also used to cense cattle to keep it fit and strong. A blessed candle put in the hands of a dying person was supposed to light his or her way to haven, offer relief and make the passage easier. In addition, blessed candles also featured in folk medicine: to prevent a sore throat, the patient inhaled candle smoke or had their neck rubbed with it; parts of the body were touched by the candle to heal ulcers, or get rid of tangled hair; sometimes combed linen tied to the candle was used to "burn" German measles or scarlet fever. ${ }^{11}$ Wax was even more important in medicine throughout Europe and not only folk medicine. It was used as binder in various ointments. It served as a warming patch, for example, in lung diseases or paralysis (attributed to witchcraft) or as an astringent (it was mixed with melted tar) ${ }^{12}$ it was also employed as a dental filling and swallowed in throat diseases and purulent mouth secretions. The famous work, Hortus Sanitatis, recommends wax charms with an addition of lark's claw to be worn for anti-disease purposes. ${ }^{13}$ When children got scared and cried incessantly, wax was poured through a linen disc to read the causes of the problem from the shape of was drops. Once finished, the collected wax would become a charm to be worn by the suffering child in order to recover or contain the fear. ${ }^{14}$

\footnotetext{
${ }^{11}$ On folk rituals involving the use of candles and was, see, e.g. Wanda DowLASZEWICZ, "Żywa tradycja 'lania świec' w Białej koło Płocka," Rocznik Muzeum Mazowieckiego w Płocku 16 (1996): 88-91; Bożena M. LiBERSKA-MARINOw, "Kult Matki Boskiej w obrzędowości dorocznej. Z badań w Opoczyńskiem," Prace i Materiaty Muzeum Archeologicznego i Etnograficznego w Łodzi. Seria Etnograficzna 29 (1989-1990), 7-19; Jerzy LECH, "Wyrób świec w Gajęcicach (pow. Radomsko)," Prace $i$ Materialy Muzeum Archeologicznego i Etnograficznego w Lodzi. Seria Etnograficzna 7 (1963), 155; Irena LECHOWA, "Relikty tradycyjnej obrzędowości dorocznej w Łęczyckiem," Łódzkie Studia Etnograficzne 16 (1974), 63; Mikołaj OlSZEWSKI, Świat zabobonów w średniowieczu (Warszawa: Semper, 2002), 114, 143, 145.

${ }^{12}$ Zbigniew Kuchowicz, Leki $i$ gusła dawnej wsi (Warszawa: Ludowa Spółdzielnia Wydawnicza, 1954), 101.

${ }^{13}$ Charlotte Angeletti, Geformtes Wachs. Kerzen, Votive, Wachsfiguren (München: Callwey, 1980), 20-21.

${ }^{14}$ Zbigniew LiBerA, Medycyna ludowa. Chłopski rozsądek czy gminna fantazja (Wrocław: Wydawnictwo Uniwersytetu Wrocławskiego, 1995), 105, 109.
} 
Consequently, wax was considered a substance with miraculous, extraordinary, magical, and health-giving properties and even having an apotropaic power; hence, making a wax votive item meant the creation of an object of extraordinary power. ${ }^{15}$ Initially, wax nuggets were offered, but from the late Middle Ages wax candles and wax votive items resembling body parts began to be seen in temples. ${ }^{16}$ The custom of offering votive candles in shrines and other holy places has survived particularly in Bavaria and Franconia, Germany, where candles of up to several meters in length are made even today. ${ }^{17}$ In other countries, including Poland, smaller candles are offered, although there are exceptions. In St Leonard's Church in Tyszowce, six over 5-meterlong, $50 \mathrm{~kg}$ candles are stored and carried by young men in processions during major church feasts. Legend has it that the candles were made to mark an event from 1655 when the Swedish army invading Poland wanted to blow up the church. They stuffed several candles with gunpowder and put them in the church. The trick misfired, and the local faithful decided to cast similar votive candles to show God their gratefulness for the saved temple. ${ }^{18}$

As noted, the use of wax in votive art was primarily due to its alleged magic function. Another important factor was the quality of the material itself, as it was relatively easy to shape to resemble a human body. ${ }^{19}$ It enabled the creation of a "double" ${ }^{20}$ whose physical semblance to a particular person encouraged the recipients of the votive image to react as if facing a living person. ${ }^{21}$ D. Freedberg points to further consequences of the need for this bodily imitation:

\footnotetext{
${ }^{15}$ Jacek OLĘDZKI, "Wota woskowe ze wsi Brodowe Łąki i Krzynowłoga Wielka,” Polska Sztuka Ludowa 14, issue 1 (1960): 5, footnote 13.

${ }^{16}$ See, e.g. Richard ANDREE, Votive und Weihegaben des Katholischen Volks in Süddeutschland, (Braunschweig: F. Vieweg und sohn, 1904), 77-85.

${ }^{17}$ Cf. Georg LiLL, "Die Kerze im Wachsgewölbe des Klosters Andechs," Bayerisches Jahrbuch für Volkskunde 1950, 60-74. Since the 18th century, procession candles have played a major role. They resemble votive candles; they contain the image of a patron saint and belong to individual pilgrimage companies, Helene and Thomas Finkenstaedt, "Vorläufiges Inventar der Prozessionstangen in Bayern," Bayerisches Jahrbuch für Volkskunde 1968, 13-44.

${ }^{18}$ Janina PeTERA, “Tyszowieckie świece, buty i konfederacja," Twórczość Ludowa 15, no. 3 (2000): 1-2.

${ }^{19}$ David FreedBerg, Potęga wizerunków. Studia z historii i teorii oddzialywania, translated by Ewa Klekot (Kraków: Wydawnictwo Uniwersytetu Jagiellońskiego, 2005), 160.

${ }^{20}$ Jean ClaIR, De Immundo. Apofatyczność i apokatastaza $w$ dzisiejszej sztuce, translated by Maryna Ochab (Gdańsk: Wydawnictwo słowo/obraz terytoria, 2007), 60.

${ }^{21}$ Freedberg, Potęga wizerunków, 161.
} 
The goal is certainly to portray a rescued person in their intact and healthy form. The only way to prove the person's saving from danger or illness, or to highlight that rescue attempts were made, is to present them so. At the same time, however, health and vigour can only be demonstrated by corporeality which is just the same as the corporeality of the one who asks or gives thanks. The greater the similarity of the image to the asker, the more appropriate the act of asking because such a presentation enables the representation of the ideas of health or saving by means of visual aids. Moreover, a divine person that is offered thanks or asked for something-for example, Christ or Our Lady - can recognize the asker or thanker beyond doubt. However, this is not just a question of recognition: the substitute body appears so real that it can be so treated. Due to its presence in an integral and intact form, it is far from all dangers; continuity between the present and past (or expected) health has been assured. ${ }^{22}$

Thus, the physical similarity between a wax effigy and a living person served both the faithful and the deity itself. By the way, it cannot be ignored (before a broader discussion of the subject) that the phenomenon of wax figures imitating the human body proved useful in two other areas: in ancient sepulchral art (wax figures of the dead) ${ }^{23}$ and in the art of medicine (wax anatomical dummies). Of course, the wax anatomical models made in the $18^{\text {th }}$ century are central to our discussion. They were made for teaching purposes but not only: they served as "curios" in private homes, were used by artists and at mobile exhibitions where they played a moralistic role and, by dramatizing obscenity and frivolity, they created an illusion of life. ${ }^{24}$ Anatomical wax figures were a product of a new era that displayed a completely different sensitivity to the human body and sensual perception where "a wax model can be a paradigmatic image of changes in the structure of knowledge and in the sphere of sensitivity." ${ }^{25}$ Also in medical discourse, they were an expression of "reduced diagnostic sensuality" 26 and a hallmark

${ }^{22}$ Ibidem, 230-231.

${ }^{23}$ Ibidem, 215-228. A classic work on this subject is the one by Julius VON SCHLOSSER, "Geschichte der Porträtbildnerei in Wachs," Jahrbuch der kunsthistorischen Sammlungen des Allerhöchsten Kaiserhauses 1910-1911, book 29, 171-258. The latest issue with Thomas Medicus's afterword: Julius vON SCHLOSSER, Tote Blicke. Geschichte der Porträtbildnerei in Wachs. Ein Versuch, (Berlin: Akademie Verlag, 1993).

${ }^{24}$ On the phenomenon of wax anatomical models, see, e.g. Anna WiECZORKIEWICZ, Muzeum ludzkich ciat. Anatomia spojrzenia (Gdańsk: Wydawnictwo: słowo/obraz terytoria, 2000), 156-192; Daniel ARASSE, "Ciało, wdzięk, wzniosłość," in Historia ciała, t. I: Od renesansu do oświecenia, ed. Georges Vigarello, translated by Tomasz Stróżyński (Gdańsk: Wydawnictwo słowo/obraz terytorium, 2011), 431-439.

${ }^{25}$ WIECZORKIEWICZ, Muzeum ludzkich ciat, 180.

${ }^{26}$ Ibidem, 182. The $18^{\text {th }}$ century saw a major shift in the imaging of anatomical iconography. An example of this is the graphics the work of Bernhardus Siegfried Albinus, Tables of the skeleton and muscules of the human body (1749), which showed the anatomical body in an idealistic, perfect and 
of the ever stronger and fundamental departure from the use of touch: "the eye became privileged in the theatre of anatomical figures. Body examination required some interaction of all senses, but the figures were not intended to generate knowledge but to expose it." ${ }^{27}$ Importantly, wax anatomical models were inspired by wax votive figures and were thought of as their visual continuation in Italian art.

\section{DEVELOPMENT OF VOTIVE OFFERINGS}

The custom of funding votive wax figures emerged, like the other wax of ferings mentioned above, in mediaeval times. The phenomenon is extremely complex. In the following centuries, it developed in many layers, in different countries and with varied intensity. The first mention of votive deposits in the form of lumps of wax weighing as much as the weight of the votive body comes from the late $10^{\text {th }}$ and early $11^{\text {th }}$ century. However, wax effigies gained in popularity no earlier than in the $13^{\text {th }}$ century in northern Europe and became widespread a century later. The custom was initiated by the foundation of the wax figure of English King Edward I, followed by those of Pope Gregory IX (for Paris), Count Artois (in Bologna), Countess von Savoyen, made by master Robertus de Beverlaco ${ }^{28}$ (in Lausanne), and the son of the prince of Burgundy, Phillip the Bold (in Vienne, 1398). In the $15^{\text {th }}$ and $16^{\text {th }}$ centuries saw the custom of offering this type of votive deposits spreading across the wealthy German, Austrian and Italian nobility (as for the latter, it was especially seen in Florence, in the Basilica della Santissima Annunziata, but also in St Joachim's Church in Siena and in the church of Santa Maria del Carmine in Naples). Some more examples are the figures placed from 1414 at the altar of St James in the parish church (today a Franciscan church) in Salzburg, the figure of Count Leonard of Görz in St Sigismund's Church in Bruneck dated 1470 or 1480 (currently at a museum in Innsbruck), or the figures of Lorenz the Great made after the Pazzi conspiracy against the Medici family (26 April 1478). ${ }^{29}$ The case of the votive effi-

\footnotetext{
harmonious form, see Karolina STOJEK-SAwicKA, "Anatomia a sztuki plastyczne w czasach nowożytnych,” Medycyna Nowożytna. Studia nad kultura medyczną 14 (2007): 23-24.

${ }^{27}$ Ibidem.

${ }^{28}$ Alfred Höck, "Frühe Wachsvotive am Elisabethengrab in Marburg/Lahn," Zeitschrift für Volkskunde 59 (1963): 61; ANGELETTI, Geformtes Wachs, 47.

${ }^{29}$ NeuHARDT, "Das Wachs im Kult," 12. A. Wieczorkiewicz (Muzeum ludzkich ciał, 163) points out that thanks to wax images "the ruler presented himself as a pious servant of God (after all, the
} 
gies of Lorenz the Great is extremely interesting. In order to show thanks to God for rescuing them, his figures made placed in as many as three temples: in the church owned by the Order of Poor Clares in Via di San Gallo, in the Basilica della Santissima Annunziata and in the Basilica di Santa Maria degli Angeli. ${ }^{30}$ The offerings were made by Verrocchio and Orsini, as noted by Vasari:

It was a great opportunity for Orsin. As a result of the assassination of Giuliano de' Medici and the danger that his brother was exposed after being wounded in the Florence cathedral, Lorenzo's friends and relatives commissioned Orsin to make votive offerings resembling Lorenzo to be placed in many sacred sites. Supported by Verrocchio, Orsini made three look-alive wax portraits relying on a wooden structure, as I mentioned elsewhere; he also strengthened them with reed and covered with wax fabric with beautiful folds that could not have been told to be more real and natural. He made heads, arms and legs of hard wax, hollow inside and naturally cast; the face was painted with oil, with hair and other details as needed. The portraits were so natural that they looked completely alive and anything but like wax, which can be easily verified on each of the three figures. One of them stands in the church of Poor Clares in Via di San Gallo, next to the glorious crucifix. This figure wears Lorenzo' robe - the same that he was wearing when found wounded in the neck; he also donned it to show himself in the window of his house as demanded by the public that had considered him dead and sought revenge. The second Lorenzo's figure, dressed in an ordinary, long Florentine gown, is on display at the Servites' Basilica della Santissima Annunziata, above a smaller door, next to where they sell candles. The third one was sent to Assisi, to the Basilica of Santa Maria degli Angeli and standed near the statue of the Virgin Mary. ${ }^{31}$

The art of making wax votive figures required considerable skill, which is why they were made by qualified craftsmen. In Italy, from the 13th century on, Boti-as the wax effigies were called-were made to order by artists known as Cerajuoli or Fallimagini. The most famous Fallimagini family was the Benintendis going back to Giacopo Benintendi of the $14^{\text {th }}$ century; his legacy was continued by two brothers, Orsino and Pagolo $\left(15^{\text {th }}\right.$ c. $) .{ }^{32}$ As shown in preserved sources, monasteries cooperated with craftsmen to establish a kind of figure-making enterprise. This is evidenced by a 1481 contract concluded between a vicar from the Basilica della Santissima Annun-

function of the figure was that of thankfulness); at the same time, the figure conveyed the splendour of the ruling family and its special position in the hierarchical structure of the world."

${ }^{30}$ Christopher HiBberT, Medyceusze, translated by Anna Kominiak-Michalska (Łódź: Wydawnictwo Łódzkie, 1994), 134.

${ }^{31}$ VASARI, Żywoty najslynniejszych malarzy, rzeźbiarzy i architektów, vol. 3, part 3, translated by Karol Estreicher (Warszawa-Kraków: Państwowy Instytut Wydawniczy, 1985), 159-160.

${ }^{32}$ AngeletTI, Geformtes Wachs, 47. 
ziata and the artist Archangelo di Zoane d'Antonio da Firenze (the friars undertook to supply wax while the craftsman the other material, such as wooden frames, natural hair, glass eyes, paint, textiles, and glitter). ${ }^{33}$

In the following centuries, the production of wax votive offerings developed more rapidly, especially in northern Europe, where the art of wax sculpture became the domain of artisans, such as wax modellers, craftsmen and even gingerbread makers. The latter mainly made smaller wax figures (approx. 20-40 cm), cast or extruded from two-part concave moulds. The moulds were made of tin or wood (pear, maple, beech, and boxwood). It is worth noting that some of them were used both for making votive items as well as gingerbread, so they served both secular and religious purposes. This type of votive offerings resembled gingerbread shapes ${ }^{34}$ with a charming and detail-rich representation of costume and folk beauty. At the same time, they were stock production and did not resemble any specific individuals. So, they often employed a specific motif: a male or female with a carefully reproduced dress (bourgeois or noble) or elaborate hairstyles. ${ }^{35}$

In addition to this type of artisans, Germany abounded in artists making full-size and three-dimensional effigies that required superior skills, artistry and commitment. In the $17^{\text {th }}$ and $18^{\text {th }}$ centuries wax figures made it to many temples across Germany, including in Abersee, Tutenhausen, Volkach, Rosenheim, Munich, Pürten. and Kaufbeuren. ${ }^{36}$ The offerings were made by both representatives of the lower classes, for example, rich peasants, and local rulers. In the latter case, two wax figures of the sons of Maximilian I, Elector of Bavaria, were funded for St Benon's Chapel in the Frauenkirchie in Munich. Both, $96 \mathrm{~cm}$ each in height, present Prince-Elector Ferdinand Maria and Prince Maximilian Philip on their knees with their hands folded for a prayer. The offering emphasizes Maximilian I's entrustment of his sons to St Benon, and their placement in the chapel area and spatial integration with the altarpiece was to guarantee protection and intercession. These ex-

\footnotetext{
${ }^{33}$ Ibidem, 47.

${ }^{34}$ Barbara Möckershoff, "Votive und Weihegaben aus Wachs," in "...Das Werk der fleissigen Bienen”. Geformtes Wachs aus einer alten Lebzelterei. Ausstellung im Diözesanmuseum Regensburg. Emmeramsplatz 1. 30. November 1984 bis 3.Februar 1985 (München-Zürich: Schnell und Steiner, 1985), 75-85.

${ }^{35}$ Theo GANTNER, "Wachs in einer «Sammlung für Volkskunde»," in Geformtes Wachs. Austellung 1980/81. Schweizerisches Museum für Volkskunde Basel (Basel: Schweizerisches Museum für Volkskunde, 1980), 7; ANGELETTI, Geformtes Wachs, 13.

${ }^{36}$ Rebecca RITZ, "Die lebengroßen angekleideten Kinder-Wachsvotive in Franken," Volksglaube Europas 1981, vol. III, 1-2; ANGELETTI, Geformtes Wachs, 48; Hans HiPP, Votivgaben. Heilung durch Glauben (Pfaffenhofen: Ludwig, 1984), 50.
} 
quisite wax sculptures bearing real resemblance to the boys are attributed to Alessandro Abondino, a wax modeller and medallist working in the Munich court between 1619 and $1645 .{ }^{37}$ As mentioned earlier, the foundation of wax effigies was not uncommon among the nobility (e.g. the votive offering of the noblewoman Helene Ainhoferin from Hohenaschau dated 1659) and lower classes (e.g. $17^{\text {th }}$-century wax figures of a rural family-parents and son-in the church in Pürten near Kraiburg; a $17^{\text {th }}$-century wax effigy of a mother and child in a bourgeois garment in Sahach). ${ }^{38}$ The "wax body" imitating the real offerer allowed the enhancement of the votive act with an extra symbolic gesture: the use of authentic clothing belonging to the portrayed individual. In this way, the votive gesture was thought to have double meaning and effect, as the offering comprised "the unique body model" together with a personal outfit owned by them. It is very important to note that the garment used for dressing up the effigy could not be casual and everyday clothes. In order to worship the sacrum properly, the portrayed person wore a festal costume to emphasize the extraordinary circumstances of serving God and stress that a miracle is occurring publicly. ${ }^{39}$ What is more, in some cases, the figures were not just clothed but even dressed up, as seen in a wax offering from Halfing dated 1628. The figure of a 12 -year-old son of rich peasants wears a costume that fits into the latest fashion trends among the children of the nobility! The boy with a very realistic face wears a doublet fastened with a chain at the waist, decorated with fancy flaps, lace, and buttons; the bottom part of the outfit is made up of the hose and fine shoes with buckles. The whole figure is finished with a red sash with a bow and a leather belt with a skewer attached on the left hip. ${ }^{40}$. Such a rich outfit, exaggerated not only in form but also, in a way, nobilitating the boy and the family, was used deliberately. It is a unique example of overdrawing a festal outfit; it pushes the boundaries set by the existing social order to depict a lower class child with a noble (meaning superior) look.

\footnotetext{
${ }^{37}$ Hubert GLASER, Um Glauben und Reich Kurfürst Maximilian I. Katalog der Ausstellung in der Residenz in München 12.Juni-5.Oktober 1980 (München-Zürich: Hirmer, 1980), 560-561.

${ }^{38}$ Barbara BRÜCKNER, "Kostüm-und trachtenkundliche Aufschlüsse bei ostbayerischen Wachsziehern," Bayesriches Jahrbuch für Volkskunde (1957): 23-26.

${ }^{39}$ This phenomenon is also true of persons depicted on painted votive plates. Everyday, ordinary clothing was only admitted in the depicting of accidents at work or for a sick person lying in bed, see August GuTZER, Votivtafeln. Bildzeugnisse von Hilfbedürftigkeit und Gottvertrauen aus der Loretokapelle in der Wallfahrtskirche zu Oggersheim (Mannheim: Archiv des Bistums Speyer, 1991), 14-15.

${ }^{40}$ BRÜCKNER, "Kostüm-und trachtenkundliche," 25.
} 
It should be emphasized that the popularity of votive wax figures in the $17^{\text {th }}$ and $18^{\text {th }}$ centuries resulted, but not only, from the theatrical and performing quality of the Baroque style itself. Moreover, the offerings reveal the visual inspiration of worshipped (and clothed) figures of Baby Jesus and the saints. A stimulus for the making of moving and dressed up figures of Baby Jesus in the Middle Ages came from mystical literature, mainly of the Cistercian and Dominican provenance. ${ }^{41}$ In mystic visions, Baby Jesus does not appear as a "static" but as an "active" being. He returns to the tree of the cross, reveals secrets, heals, and permits (especially nuns) to be rocked and nursed. The literary visions of the Divine Infant in the $13^{\text {th }}$ century were transformed into a specific, iconographic image. It was in the same century that the wax figurines of Baby Jesus began to grow in popularity. They were dressed in festive robes embroidered with a golden thread, decorated with bows and wigs made of natural hair. This type of sacred images, well-established in the $15^{\text {th }}$ and $16^{\text {th }}$ centuries, was obviously upheld in the Baroque. Besides, the $17^{\text {th }}$ and $18^{\text {th }}$ centuries saw the increased role of dressed figures of saints with movable limbs and large in size (some up to $130 \mathrm{~cm}$ in height), as well as those with the body made of wooden frames to support and display various textile relics (the sculpture of St Nicholas of Flühe in a church in Sachseln), in the religious life. ${ }^{42}$ The wax body of Baby Jesus, as well as the textile quality allowing the use of clothes to transform mobile sculptures or sculptures-frames, ${ }^{43}$ undoubtedly delineated a certain visual and design domain readily explored by votive offering makers. And such offerings, on top of their symbolism, were nothing more than a more or less mobile sculpture wearing natural clothes.

\section{WAX FIGURES IN FRANCONIA}

A separate and quite unusual phenomenon is the votive wax effigies (especially children aged between three and 12) funded in Upper and Lower

\footnotetext{
${ }^{41}$ Friederike SchmitT-BREUninger, Eugen Roth, Ein Kind ist uns geboren. Christkind-Figuren aus sechs Jahrhunderten (München: Prestel Verlag, 1978), 10-12.

${ }^{42}$ Gislind M. RiTZ, "Eine barocke Ankleidefigur,” Bayerisches Jahrbuch für Volkskunde (1963): $109-112$.

${ }^{43}$ On accessories to sacred figurines - costumes, robes, dresses, hair, see, e.g. in: Grażyna JURKowlanIEC, Epoka nowożytna wobec średniowiecza. Pamiątki przeszłości, cudowne wizerun$k i$, dzieła sztuki (Wrocław: Wydawnictwo Uniwersytetu Wrocławskiego, 2008), 187-202 (also contains extensive literature on the subject).
} 
Franconia (Bamberg and Würzburg dioceses). This type of votive deposits became commonplace around 1880 to reach its climax in 1900-1910 and die out in the 1950s. The most famous makers of such votive figures were Friedrich Roppelt of Bamberg and the Bamberg-based company Poppenberger. ${ }^{44}$ Today, the largest "collections" of these are to be seen in: the Wallfahrtsmuseum in Gößweinstein, the Diocesan Museum in Bamberg, St Anna's Chapel in Marienweiher and a church in Vierzahnheiligen with its votive exhibits (Votivkammer). ${ }^{45}$

Franconian votive offerings were always made in a similar way: they had wax faces and hands (less often feet), while the remaining limbs were made of wood, metal and various lining or padding materials. The offerings were modelled after dolls; hence, like dolls, they wore wigs made of natural or artificial hair, had glass eyes, and open mouth. The clothes were very significant. They were the real costumes wore by children (girls were often dressed like for the First Communion ceremony); moreover, the effigies wore a complete outfit: authentic underwear, stockings, or leather shoes. The girl figures were decorated with rosaries, flower bouquets held in the hands and wreaths on the head. The flower bouquets or wreaths naturally emphasized the moment of entrustment and alluded to the solemn atmosphere of a religious festival, as such "artifacts" were used during important religious events or processions. The figures were placed in glass vitrines, showcases and cassettes, sometimes with a wallpaper background. A text was often attached to the front pane. It contained the child's name (alternatively, the names of the parents) and the time of making the offering. All these items and additions made offerings very expensive (before World War I, one such votive offering cost DM 70 while a worker's salary was between DM 25 and 110). This meant that many families could not afford them, so often the figure was funded a few years after the child's recovery to allow for extra time to collect the money. ${ }^{46}$

In Vierzahnheiligen, the offering of votive deposits was so common in the Middle Ages and later that the Votivkammer there became to be known

\footnotetext{
${ }^{44}$ ANGELETTI, Geformtes Wachs, 49.

${ }^{45}$ See Gislind M. RitZ, "Eine barocke," 1-63; Kriss, GocKerell, Bilder und Zeichen, 105; Karl H. BrÜCKNER, Günter Dippold, Peter Ruderich, Christine SchweßINGer, Gößweinstein. Sakralne Mitte der Fränkischen Schweiz, (Staffelstein: Bornschlegel, 1998), 82; Marcus A. DANZEL, Karl H. BRÜCKNER, Peter RUdERICH, Marienweiher. Der Wallfahrt im Frankenwald (Dresden: Heinrichs-Verlag, 2002), 12-14.

${ }^{46}$ Cf. Ritz, "Eine barocke," 6-12.
} 
as the Wachskammer, ${ }^{47}$ as the variety of deposited wax votive items was really impressive: body parts, wax lumps, sculptured wax compositions on religious themes, and, of course, full-size figures of children and adults. In his article of 1926, I.M. Ritz mentioned the figures of children and two wax figures of soldiers. ${ }^{48}$ The funding of wax figures of adults was documented by J. von Schlosser. A photograph attached to his article shows large wooden showcases with figures of adult women inside. Unfortunately, the present-day Votivkammer has been vacated of many of items from the original collection. The exposed offerings are mostly wax babies in swaddling bands (modelled after Baby Jesus) and small, doll-like figurines. Some of these were originally exhibited in showcases, but now they have been deprived of the symbolic setting, thus somewhat distorting their reception or even making it worse.

More interesting and higher quality items can be seen in St Anne's Chapel in Marienweiher. Unfortunately, in this case, the figures are "overwhelmed" by other votive offerings (images, candles, devotional articles). Although some of them need conservation, the offerings (more than ten, including two of children in swaddling) are items of fine workmanship originating in the Bamberg workshops, and they represent classic-type, independent votive figures. They mostly come from the 1920s, are placed in glass cassettes, some without any labels or information.

The largest and most beautifully exhibited wax figure collection is housed in the Wallfahrtsmuseum in the Holy Trinity shrine in Gößweinstein. After several years of renovation of the interior and thorough conservation of several dozen voting offerings, the museum was reopened in 2008 to show off a "fresh" exhibition and a professional catalogue of exhibits authored by Dr Regina Urban. The Gößweinstein basilica used to be one of the key pilgrimage destinations where the depositing of wax figures was very popular (from the mid-1 $19^{\text {th }}$ century to 1952 ). In total, 108 items have been preserved. 25 effigies of children and two of adults are currently on display in the museum (the other ones are still being conserved, three are stored in the Diocesan Museum in Bamberg). It is worth noting that many of these figures were funded by emigrants of the impoverished Franconian Jura who were leaving for the United States at the beginning of the $20^{\text {th }}$ century. This testifies to

\footnotetext{
${ }^{47}$ Most of the valuable wax figures kept in this shrine have been lost; see Josef M. RiTz, "Die Wachskammer zu Vierzehnheiligen," in St. Heinrichskalender. Familienkalender für Frankenvolk 1926 (Bamberg: Feuchtwangen, Sommer \& Schorr, 1926), 85-91.

${ }^{48}$ Ibidem, 87.
} 
their resolve to maintain religiousness but also confirms the popularity of the shrine itself.

The oldest preserved figure with exceptional beauty is the Praying Girl going back to the mid- $19^{\text {th }}$ century. It was found by accident in the church tower under a defunct clock mechanism where it had been placed probably in 1956 upon the transfer of the church Votivkammer. She wears a braid (made of real hair) and, as the only of all the figures in Gößweinstein, has her hands folded for prayer. ${ }^{49}$ Other child effigies placed in the showcases show a varied level of workmanship: from very poor and provincial "scary dolls," to outstanding, touching, and charming pieces in the frame of votive creation. One of the most important and skilfully made votive offerings is a gentle and almost fairy-tale image of Johann Häffner from 1923, called Little Master. This is one of the offerings in Gößweinstein funded by the German settles in America. The most striking element of the figure is a meticulously rendered dress, with rare tailoring and a common motif of a flower bouquet in the hands. ${ }^{50}$ An equally charming figure is that of Maria Schlemmer dated 1938. At the age of 9 months, the girl caught pertussis and pneumonia. After her miraculous healing, the parents and the girl went on a pilgrimage to Gößweinstein where they deposited their offering. ${ }^{51}$ Almost no information has been preserved about the reasons behind most of the votive offerings. Still, the stories that are known and substantiated make the items even more valuable. The cases of Heinrich Planek from 1952 and Eva Dürrbeck from 1955 are two examples of such preserved narratives. The effigy of Heinrich Planek shows a meditating boy who was bitten by a dog at the age of two in 1950. As a result, an infection developed in his entire body. Physicians from the Bayreuth hospital informed the family about boy's clinical death, and they refused to continue the treatment. The child was taken home and entrusted to God in the Gößweinstein shrine. When boy recovered, the parents decided to fund a votive offering. ${ }^{52}$ The effigy of Eva Dürrbeck portrays a three-year-old girl who was run over by a motorcycle. Her skull base cracked; she suffered from complete paralysis and fell into coma. The doctors gave her no chance, but Eva recovered miraculously. The girl's father ordered a votive item at the famous company Poppenberger for

\footnotetext{
${ }^{49}$ Regina URBAN, Unterwegs im Wallfahrtsmuseum Gößweinstein (Gößweinstein: Wallfahrtsmuseum Gößweinstein, 2008), 37.

${ }^{50}$ Ibidem, 25.

${ }^{51}$ Ibidem, 30.

${ }^{52}$ Ibidem, 36.
} 
as much as DM $150,{ }^{53}$ which is seen in the excellent quality of the figure and its unique charm. As mentioned earlier, no records have survived on most of the figures that would help track back their origin and reason for making. One of such puzzling offerings is the beautiful and expensive figure of Joseph Pöhlmann dated 1904 (the son of a master blacksmith from Kirchehrenbach)..$^{54}$

The most recognized items from Gößweinstein include the famous figure of Katharina Kupfer (née Wagner) funded by her parents Andreas and Katharina Wagner in 1952. The offering portrays Katharina Wagner who died in 1947 at the age of 24 . When comparing the effigy with her photo from the newspaper obituary, the similarity between the girl and her wax double is unquestionable. No wonder, the figure was ordered at Poppenberger, Bamberg's most renowned and highly qualified supplier. ${ }^{55}$ An additional value of the figure is a fabulously colourful costume and crown-a typical folk wedding dress. In this way, having collected the appropriate sum of money a few years after their daughter's departure, the desperate parents placed her finely clothed effigy in the place of worship of the Holy Trinity. The offering of Katharina Kupfer does not symbolize recovery, nor does it indicate regained hope: it is a manifestation of parents' love for their grownup daughter. It is yet another context for votive offering that did not always followed the act of miraculous recovery, healing or rescue. There is a sizeable group of items (mainly painted boards) depicting dead persons lying in beds in deathly shirts or with crosses in their hands; ${ }^{56}$ such votive offerings were thanksgiving gifts supporting prayers for the departed. ${ }^{57}$ So both health and death can be blessed, the latter closing with happy entrance into the Kingdom of Heaven.

Another figure from Gößweinstein is a votive offering of a man dated 1905. It takes after shop mannequins and is not as realistically refined a portrait as that of Katharina Kupfer (archival photos show that originally the man had worn a moustache).

The prestige of votive deposits at the Gößweinstein shrine is evidenced by the fact that three of them are exhibited at the Diocesan Museum in

\footnotetext{
${ }^{53}$ Ibidem, 28.

${ }^{54}$ Ibidem, 25.

${ }^{55}$ Ibidem, 34.

${ }^{56}$ Sometimes crosses were placed above the figure heads, see Leopold SCHMIDT, "Ausstellung Südtiroler Volkskunst. Katalog,” Österreichische Zeitschrift für Volkskunde 1 (1960): 248.

${ }^{57}$ Lenz KRISs-RETTENBECK, Bilder und Zeichen religiösen Volksglaubens (München: Callwey, 1971), 53.
} 
Bamberg as fine examples of brilliant votive art from Franconia (a girl from Reuth dated 1907; the effigy of Johann Fuchs dated 1900; a child in swaddling dated 1906). The other two items on display are the offerings of a girl from Hollfeld ( $1^{\text {st }}$ or $2^{\text {nd }}$ decade of the $20^{\text {th }}$ century) and of a child in swaddling from Burgwindheim (around 1900).

The wax figures from Franconia are unique pieces of votive art for several reasons. First, they were made within a relatively small and, in a sense, closed region of specific space, religion, and culture. Hence the iconography of the Franconian figures reveals a limited and non-evolving formula that has exhausted after a hundred years. Another attribute of these items is the distinct and perhaps even excessively obtrusive influence of the then $19^{\text {th }}$ century fashion for dolls: most votive deposits portraying children exhibit the characteristics of a valuable, ideal, and desirable toy. That is why, the effigy of a particular child was not based on individual physical characteristics but conveyed an idealistic image. The opinion of D. Freedberg quoted above emphasizes the importance of similarity of a wax figure to its living model: it complemented the act of offering and allowed God to recognize a particular person. However, it is evident that most of the Franconian votive offerings are not mirror images of their models. Already J. von Schlosser noticed the lack of close similarity or only a slight similarity to the offerer, characteristic of this group of German wax figures. ${ }^{58}$ However, this feature is a sign of the process of emancipation of wax images. Voting deposits would usually strongly resemble living people but if they did not, they did not lose their symbolic status. ${ }^{59}$ They were more than just a substitute portrait of a person as they were "entangled" in the centuries-old rite of votive offering, i.e. a spiritual vow between the offerer and deity. It should be highlighted that the Franconian wax figures had their own distinctive and individualistic means of expression. The key elements that added to that "strengthened personalization" were the real, personal dress of a child or adult and a personal rosary that adorned the figure. The final act transforming the wax figure/puppet/doll into a child or adult was a label attached to the display case to certify the votive intention. Preserved church documents, archives, or labels attached to display cases are also an important source of medical knowledge about the diseases of the late $19^{\text {th }}$ and early $20^{\text {th }}$ century. The prevailing ones were pertussis, lung diseases, diphtheria and tetanus. ${ }^{60}$ If

\footnotetext{
${ }^{58}$ VON SCHLOSSER, Tote Blicke, 60.

${ }^{59}$ Thomas Medicus, "Nachwort," in Julius von SCHLOSSER, Tote Blicke, 141.

${ }^{60}$ Ritz, "Eine barocke," 16.
} 
they referred to accidents, we learn about the treatment methods and procedures, which, unfortunately, often proved ineffective.

The figures of Franconia document the last stage of one of the most popular votive formulas. Their specific confined framework, repetitive visual design, and limited means of expression essentially make them mannerist items. This mannerism is an expression of the decline of votive art and the decline of the votive offering as such. Still, these items are remarkably charming and graceful and convey an undeniable tinge of mystery. Those seemingly puppet-like figures, sealed tightly within the frames of display cases, seem to at a standstill only for a moment as if asleep upon passing from death to life. Although the attached labels already testify to miracles, the figures seem to be still awaiting a miracle.

Despite the many features that distinguish Franconian votive offerings from wax sculptures from other regions, all these items share a timeless and cross-boundary idea perfectly captured by H. Belting. He appreciated their considerable role in the public and religious life by pointing out that, "an artificial body has assumed the religious representation of a living body, both retrospectively-with regard to their life as a citizen - and prospectivelyby looking towards the future resurrection of the body. In this way, their presence in the process of transformation into an image filled the gap between the death of the person and the Last Judgement."61

\section{LIST OF IMAGES}

1. Votive wax figure of a man - front and back (the type made with a wooden mould), $18^{\text {th }} \mathrm{c}$., Germany. (the image from: Richard Andree, Votive und Weihegaben des Katholischen Volks in Süddeutschland (Braunschweig: F. Vieweg und sohn, 1904).

2. Votive wax figure of a woman - front and back (the type made with a wooden mould), 18th c., Germany. (the image from: Richard Andree, Votive und Weihegaben des Katholischen Volks in Süddeutschland (Braunschweig: F. Vieweg und sohn, 1904).

3. Exhibition of votive wax figures, Wallfahrtsmuseum, Gößweinstein, Germany (photo by Jowita Jagla).

4. Praying Girl-a votive wax figure, $19^{\text {th }}$ c., Wallfahrtsmuseum, Gößweinstein, Germany (photo by Jowita Jagla).

5. Votive figure of Johann Häffner, 1923, Wallfahrtsmuseum, Gößweinstein, Germany (photo by Jowita Jagla).

6. Votive figures of Katharina Kupfer (née Wagner), 1952, and a man of 1905, Wallfahrtsmuseum, Gößweinstein, Germany (photo by Jowita Jagla).

\footnotetext{
${ }^{61}$ Hans Belting, Antropologia obrazu. Szkice do nauki o obrazie, translated by Mariusz Bryl, (Kraków: TAiWPN Universitas Kraków, 2007), 130.
} 


\section{SELECTED BIBLIOGRAPHY}

ANGELETTI, Charlotte. Geformtes Wachs. Kerzen, Votive, Wachsfiguren. München: Callwey, 1980.

ARASSE, Daniel. "Ciało, wdzięk, wzniosłość." In Historia ciała, t. I: Od renesansu do oświecenia, ed. Georges Vigarello. Translated by Tomasz Stróżyński. Gdańsk: Wydawnictwo słowo/obraz terytorium, 2011.

Belting, Hans. Antropologia obrazu. Szkice do nauki o obrazie. Translated by Mariusz Bryl. Kraków: TAiWPN Universitas Kraków, 2007.

ClaIR, Jean. De Immundo. Apofatyczność i apokatastaza w dzisiejszej sztuce. Translated by Maryna Ochab. Gdańsk: Wydawnictwo słowo/obraz terytoria, 2007.

DAnZel, Marcus A., Karl H. BRÜCKNER, Peter RUderICH. Marienweiher. Der Wallfahrt im Frankenwald. Dresden: Heinrichs-Verlag, 2002.

FreEdBerg, David. Potęga wizerunków. Studia z historii i teorii oddziaływania. Translated by Ewa Klekot. Kraków: Wydawnictwo Uniwersytetu Jagiellońskiego, 2005.

GuARDinI, Romano. Znaki święte. Translated by Józef Birkenmajer. Wrocław: Wydawnictwo Wrocławskiej Księgarni Archidiecezjalnej, 1982.

Hibbert, Christopher. Medyceusze. Translated by Anna Kominiak-Michalska. Łódź: Wydawnictwo Łódzkie, 1994.

JuRkowlaniec, Grażyna. Epoka nowożytna wobec średniowiecza. Pamiatki przeszłości, cudowne wizerunki, dzieła sztuki. Wrocław: Wydawnictwo Uniwersytetu Wrocławskiego, 2008.

KRISS, Rudolf, Nina GocKERELl. Bilder und Zeichen der Frömmigkeit. München: Bayerisches Nationalmuseum, 1995.

KRISS-ReTtenBECK, Lenz. Bilder und Zeichen religiösen Volksglaubens. München: Callwey, 1971.

LIBERA, Zbigniew. Medycyna ludowa. Chłopski rozsądek czy gminna fantazja. Wrocław: Wydawnictwo Uniwersytetu Wrocławskiego, 1995.

OlszewsKi, Mikołaj. Świat zabobonów w średniowieczu. Warszawa: Semper, 2002.

PFISTERMEISTER, Ursula. Wachs. Volkskunst und Brauch. Nürnberg: Hans Carl, 1982.

SCHLOSSER, vON Julius. Tote Blicke. Geschichte der Porträtbildnerei in Wachs. Ein Versuch. Berlin: Akademie Verlag, 1993.

SCHMitT-BReuninger, Friederike, Eugen Roth. Ein Kind ist uns geboren. Christkind-Figuren aus sechs Jahrhunderten. München: Prestel Verlag, 1978.

URBAN, Regina. Unterwegs im Wallfahrtsmuseum Gößweinstein. Gößweinstein: Wallfahrtsmuseum Gößweinstein, 2008.

VASARI. Żywoty najslynniejszych malarzy, rzeźbiarzy i architektów, vol. 3, part 3. Translated by Karol Estreicher. Warszawa-Kraków: Państwowy Instytut Wydawniczy, 1985.

WieCZORKIEWICZ, Anna. Muzeum ludzkich ciat. Anatomia spojrzenia. Gdańsk: Wydawnictwo: słowo/obraz terytoria, 2000. 


\title{
FROM A NOBLE SUBSTANCE TO AN IMITATIVE BODY. THE PICTURE AND THE MEANING OF WAX FIGURES IN A VOTIVE OFFERING
}

\author{
Summary
}

In a wealth of votive gifts, the wax ones undoubtedly deserve special attention. They were common as early as in the Middle Ages, and they were used until the $20^{\text {th }}$ century. There was a variety of such votive offerings, starting with candles, through lumps of wax, and ending with fullscale wax figures that started being used as a votive gesture at the break of the $13^{\text {th }}$ and $14^{\text {th }}$ centuries in the north of Europe. In the $15^{\text {th }}$ and $16^{\text {th }}$ centuries this custom became popular among the wealthy German, Austrian and Italian noblemen. Making wax votive figures took a lot of skill so they were made by specially qualified artists (in Italy wax figures called Boti were produced by sculptors called Cerajuoli or Fallimagini). Religious orders collaborated with the artists-artisans, undertaking to supply wax, whereas the artisans prepared wooden frames, natural hair, glass eyes, paints, textiles and brocade. In the following centuries, the production of wax figures developed ever more dynamically, especially in the north of Europe, with less skilled wax modellers, artisans and gingerbread makers often being their producers. The latter ones mainly made smaller wax figures, cast or squeezed from two-part concave models (this type of items in their form and type reminded of figures made of gingerbread).

Wax votive figures (especially of children aged three to 12) funded in the area of Upper and Lower Franconia (the Bamberg and Würzburg dioceses) from the mid- $19^{\text {th }}$ to the mid- $20^{\text {th }}$ century are a separate and rather unusual phenomenon. Popularity of this votive offering became stable about 1880, in the years 1900-1910 it reached its climax; and in the 1950s it came to an end. Franconian offerings were always constructed in a similar way: they had wax faces and hands (more rarely feet), and the other members were made of wood, metal and some other padding materials. Dolls were a dominating model for the production of these votes, and that is why, like dolls, they had wigs made of natural hair on their heads, glass eyes and open mouths. A very important role was played by clothing, in which figures were willingly dressed; they were children's natural, real clothes (girls were often dressed in the First Communion dresses); moreover, the effigies had complete clothing, which means they had genuine underwear, tights, leather shoes. The figures were supplied with rosaries and bouquets held in their hands, and on the heads of girls there were garlands. The figures were put in cabinets and glass cases, sometimes with wallpaper on the back wall, and they had a longer text on the front glass with the name of the child, or possibly of its parents, and the time when the figure was offered.

Despite the many features making the Franconian offering deposits different from votive figures from other regions, all these items are joined by a timeless and universal idea, in which - to quote H. Belting_- "an artificial body has assumed the religious representation of a living body..."

Key words: wax, wax figure, votive offering, iconography, symbolism

Translated by Konrad Szulga

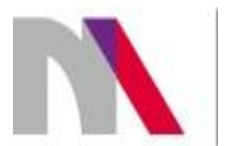

The preparation of the English version of Roczniki Humanistyczne and its publication in electronic databases was financed under contract no. 836/P-DUN/2018 from the resources of the Minister of Science and Higher Education for the popularization of science. 


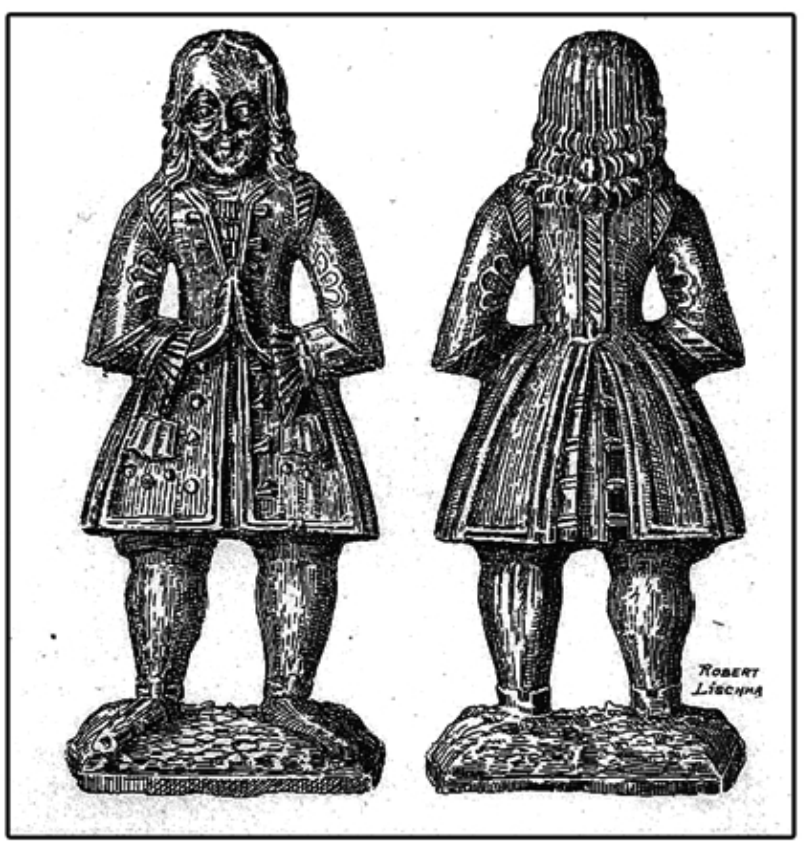

1. Votive wax figure of a man-front and back (the type made with a wooden mould), $18^{\text {th }}$ c., Germany. (the image from: Richard Andree, Votive und Weihegaben des Katholischen Volks in Süddeutschland (Braunschweig: F. Vieweg und sohn, 1904)
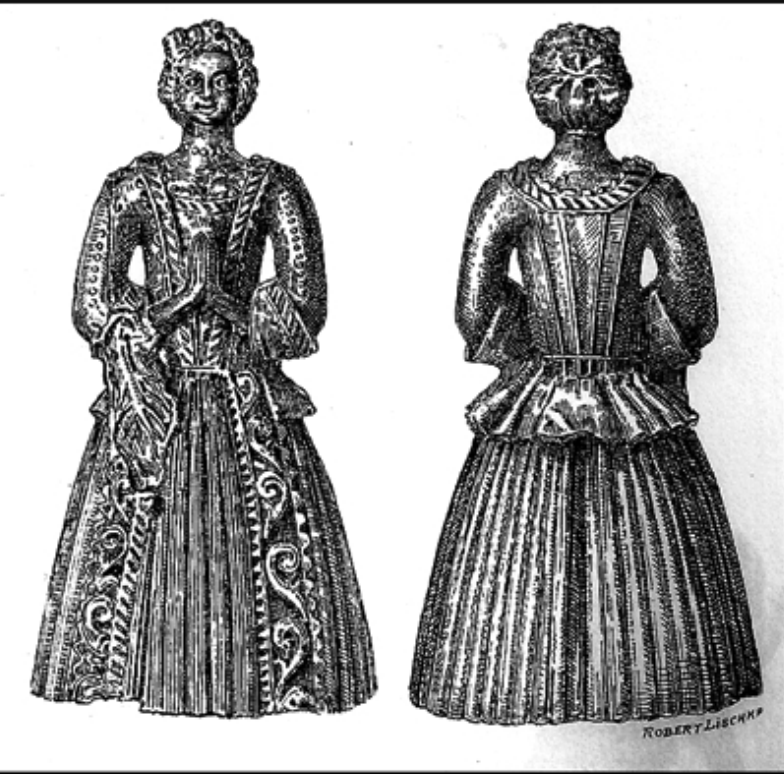

2. Votive wax figure of a woman - front and back (the type made with a wooden mould), $18^{\text {th }}$ c., Germany (the image from: Richard Andree, Votive und Weihegaben des Katholischen Volks in Süddeutschland (Braunschweig: F. Vieweg und sohn, 1904) 


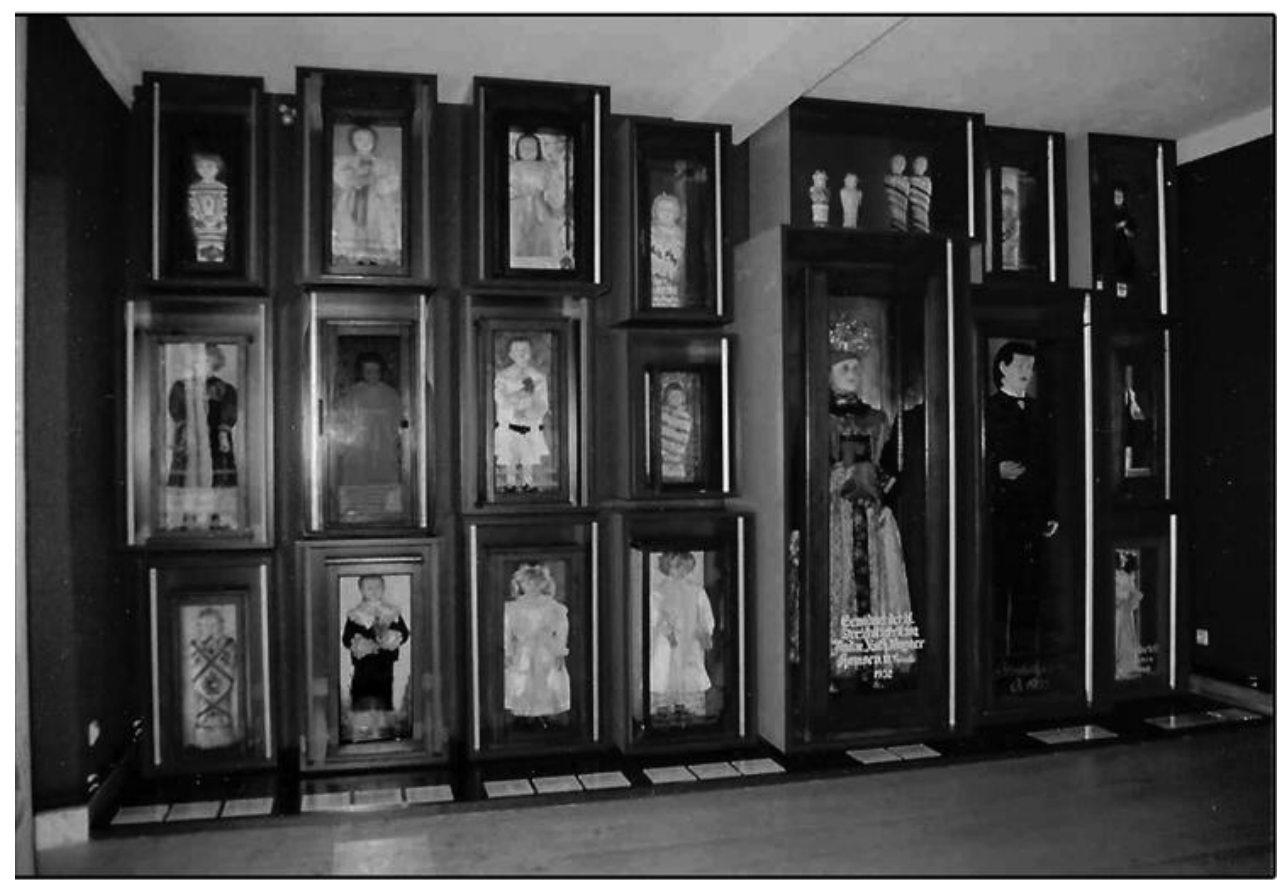

3. Exhibition of votive wax figures, Wallfahrtsmuseum, Gößweinstein, Germany (photo by Jowita Jagla)

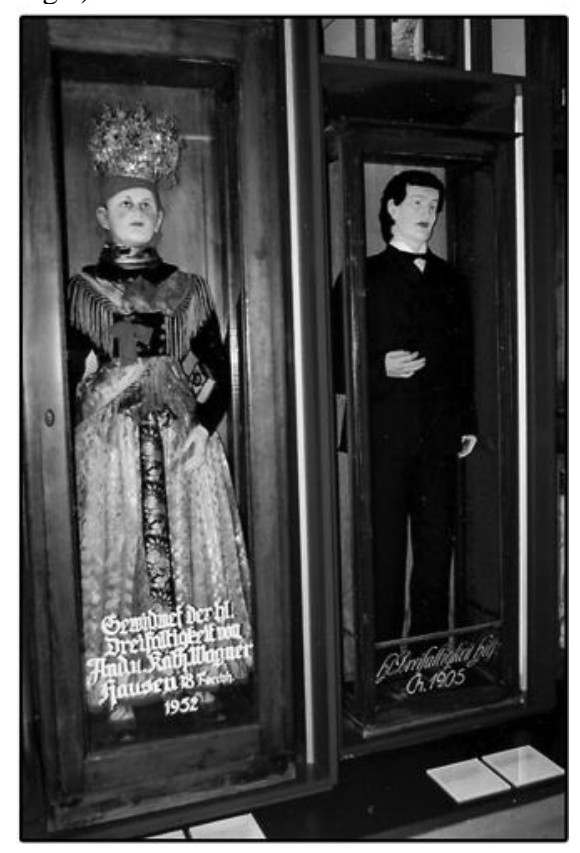

4. Praying Girl - a votive wax figure, $19^{\text {th }} \mathrm{c}$.,

Wallfahrtsmuseum, Gößweinstein, Germany (photo by Jowita Jagla) 


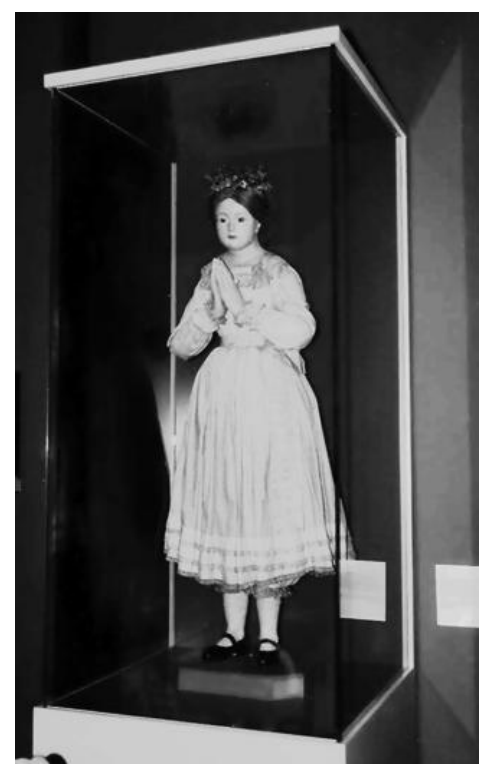

5. Votive figure of Johann Häffner, 1923,

Wallfahrtsmuseum, Gößweinstein, Germany (photo by

Jowita Jagla)

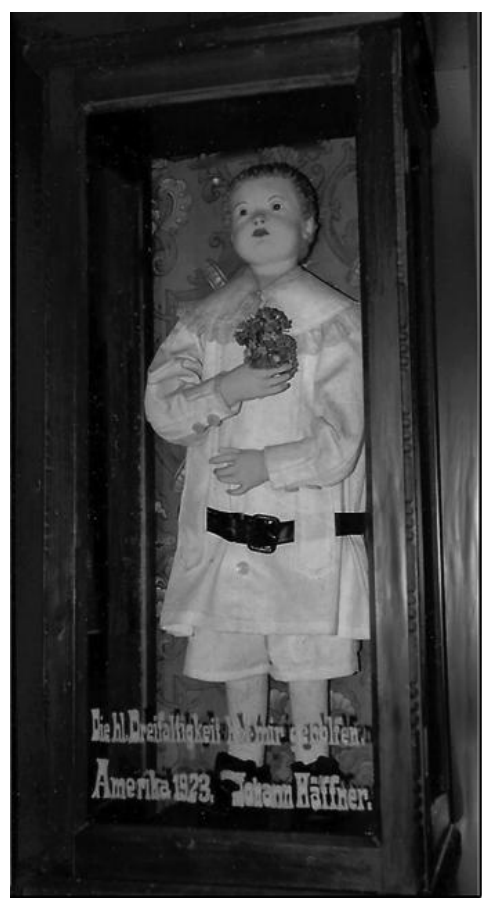

6. Votive figures of Katharina Kupfer (née Wagner), 1952, and a man of 1905, Wallfahrtsmuseum, Gößweinstein,

Germany (photo by Jowita Jagla) 